821.163.41-1.09" $15 / 16$ “

https://doi.org/10.18485/msc.2018.47.2.ch12

Гордана С. ПОКРАЈАЦ* Универзитет у Новом Саду Филозофски факултет
Оригинални научни рад

Примљен: 25. 9. 2017.

Прихваћен: 27. 12. 2017.

\title{
ПОКЛАДНИ ДУХ ДУБРОВАЧКИХ ПСЕУДОМАСКЕРАТА
}

\begin{abstract}
Под утицајем италијанских карневала и књижевности, дубровачка покладна поезија подражавала је тосканске маскерате, у првом реду сијенске и фирентинске. Дубровачки покладни песници XVI и XVII столећа су одређеним песмама давали особине сијенских цингарески и фирентинских покладних канцона, а то су чинили и у случајевима када их нису намењивали покладним ситуацијама. Реч је о псеудомаскератама, а условно речено примере псеудомаскератне поезије пружају извесна дела Мавра Ветрановића („Ремета”, „Орлача Риђанка Котору говори проностик”), Антуна Сасина („Робиња”), Савка Бобаљевића („Мајка Венере иште Купида, свога сина, од ње изгубљена”), Стијепа Ђурђевића (Дервищ) и других песника. У раду ћемо покушати показати у чему се, поред сличности са италијанским маскератама, дубровачке маскерате од њих одвајају. У циљу указивања на њихове особености, настојаћемо да истакнемо и аутентичне појединости настале надградњом на постојеће изворе, те да образложимо проблематичност одређења „псеудомаскерате" и његово неадекватно непримењивање на поменута дела.
\end{abstract}

Кључне речи: покладе, маскерате, псеудомаскерате, ренесанса, Дубровник, Италија, „Ремета”, Дервиш, петраркизам.

Процес транспоновања вишевековне традиције карневала у дубровачко културно окружење, утицао је на успостављање одређене традиције карневалског ритуала у ренесансном Дубровнику. Изразит подстицај развоју покладних песама ${ }^{1}$, пружио је родоначелник фирентинске покладне лирике - Лоренцо Медичи (Превитера 1939: 204-221). Нарочито је његова песма „Тријумф Бахуса и Ариадне” (Trionfo di Bacco e d'Arianna) са својим слав-

*tadzio.gordana@gmail.com

${ }^{1}$ Бавећи се поетиком маскерата, Милорад Медини је у два своја дела указао на утицај италијанских маскерата на дубровачке: Dubrovačke poklade u XVI. i XVII. vijeku i Čubranovićevi nasljednici, Program C. K. Velike državne gimnazije u Dubrovniku za 1897-98, Dubrovnik, 1898, 19-40; и Povijest hrvatske književnosti u Dalmaciji i Dubrovniku, I, Matica hrvatska, Zagreb, 1902, 143-161. Павле Поповић истиче да је маскерата или покладна песма књижевни род који је створио карневал, најпре у Италији „где је већ у XV веку цветао, па се после, у XVI веку пресадио у Дубровник” (Поповић 1913 : 144). 
ним рефреном - како је лепа младост која неумитно пролази („Quant’ è bella giovinezza/ che si fugge tuttavia”) (Леви 1908: 260) - пренела наслеђе латинске мудрости и у ренесансни Дубровник. Поетичка обележја Лоренцових карневалских песама (canti carnascialeschi) приближила је дубровачким песницима ренесансна антологија фирентинских покладних песама, коју је приредио Антон Франческо Грацини, звани Ласка². Под утицајем италијанских карневала и књижевности дубровачка покладна поезија почела је подражавати тосканске маскерате, па су се и учесници преображавали у најразноврснија обличја, певајући песме и правећи шале које су понекад биле „безумне” (Јиречек 1899: 425). Поједине маске су певале ласцивне песме упућене Дубровкињама, што је био својеврсни одјек фирентинске покладне канцоне са позивањем на љубавно уживање, а затим и сијенских цингарески ${ }^{3}$, које су женама предсказивале судбину и давале љубавне савете. Пренете из италијанских градова, носећи са собом несуздржану радост и ентузијазам, ове покладне песме су у дубровачкој средини наставиле да на особен начин - кроз песму, музику и плес - одражавају изворни дух и атмосферу ренесансних светковина.

Маскерата - као врста пригодне лирске песме потекле из италијанске литературе и везана првенствено за извођење о покладним светковинама - значајно је утицала и на настанак песама које су веома подсећале на маскерате, али нису бивале намењене карневалском казивању нити су имале пригодни карактер. Тако су се у ренесанси на маскератној традицији развили одређени књижевни облици који јој заправо, као подврсти покладне поезије, нису припадали. Посебну пажњу привлаче песме XVI и XVII столећа које подсећају на маскерату, али немају суштинска обележја маскерате. Реч је о песмама: „Ремета” (обе песме под овим насловом), „Орлача риђанка Котору говори проностик”, „Орлача риђанка Перашту говори”, „Орлача риђанка речено у Блату рибаром” - Мавра Ветрановића, „Робињица” - Антуна Сасина, „Мајка Венере иште свога сина од ње изгубљена” - Савка Бобаљевића и спев Дервиш - Стијепа Ђурђевића. Миливој Петковић у својој студији половином ХX столећа под насловом Дубровачке маскерате ${ }^{4}$ - као синтези свих дотадашњих истраживања о маскератној поезији - ове песме назива „псеудомаскератама”. Маскерата је у основи структурирана као монолог необичне и костимиране личности која се на самом почетку представља публици, говорећи одакле долази и чиме се бави (носећи маску одређене професије); она на комичан начин говори о свом тешком животу и на крају монолога обично

${ }^{2}$ A. F. Grazzini, Tutti i trionfi, cari, mascherate ò canti Carnascialeschi andati per Firenze, del tempo del Magnifico Lorenco vecchio de'Medici fino all anno 1559, Firenze, 1559.

${ }^{3}$ Реч је о маскератама у којима су маске имитирале „циганке” и „виле” за време поклада; рецитовале су, певале и предсказивале судбину, тражећи понекад заузврат од жена награду. Говорећи о маскератама, Бранко Водник пружа опис фирентинских карневала који су утицали на развој дубровачке маскератне поезије, нарочито цингарески, као на пример Чубрановићеве Јеђупке (Водник 1913: 97-98).

${ }^{4}$ Миливој А. Петковић, Дубровачке маскерате, САНУ, Посебна издања, књ. CLXVII, Одељење литературе и језика, књ. 1, Београд, 1950.

5 Драгољуб Павловић истиче да је Петковићево дело најчвршће полазиште у истраживању маскератног жанра (Павловић 1954: 339-347). О значају Петковићеве студије излаже Тања Ракић (Ракић 2013: 287-295). 
тражи од слушалаца награду - у виду јела, пића, или позива жена на љубавно уживање. У Дубровнику је одјек усмене традиције подстакао и употребу осмерачког стиха у маскератној лирици, што је на пример, случај у Ветрановићевим маскератама - „Трговци Армени и Индијани”, „Двије робињице” и Ланци „Алемани, трумбетари и пифари”.

Жанровско дефинисање „псеудомаскерате” које М. Петковић примењује на поменутих пет Ветрановићевих песама и песме А. Сасина, С. Бобаљевића и С. Ђурђевића, у суштини представља проблематично одређење, којим су се са различитих аспеката бавили и историчари књижевности и проучаваоци пре настанка Петковићеве студије о дубровачким маскератама. Луко Зоре (Зоре 1884: 145-175) је у сагледавање маскерата у оквиру хероикомичних песама укључио и комичне спевове, као што је Дервии Стијепа Ђурђевића. Павле Поповић истиче да поред маскерата Мавро Ветрановић има још једну песму „која је делимично шаљива и која има нечег што на маскерату подсећа. То је чувена и лепа његова песма Ремета" (Поповић 1913: 146), спевана у осмерцу. У XVII веку, наводи Поповић, маскерата се губи, а „имитација Јеђупке се још наставља" (Поповић 1913: 179). Као једно од најважнијих дела ове врсте, односно имитацијаิ Чубрановићеве Јеђупке, он издваја Дервиша Стијепа Ђурђевића, напомињући да је у питању пародија Јеђупке, њене шесте песме: „и овде љубавник изјављује љубав оној која за његову љубав неће да зна, само је овде љубавник Турчин, дервиш, комичан, и његова љубавна изјава је смешна" (Поповић 1913: 180). Милан Решетар (Решетар 1926: 111-122) се бавио истраживањем специфичности и међусобних разлика дубровачких маскерата у ренесанси. Он прави дистинкцију између „пјесни од машкарате” које су се изводиле на улици, и салонских какве су јеђупке - оне се „нису пјевале у јавности, него су се само читале под кућним кровом" (Решетар 1926: 113). С друге стране, у уличним маскератама је била важна музика, уз плес, а у Дубровнику су оне извођене по узору на фирентинске тако што су „поједине особе или цијеле дружине ишле маскиране уз свирку” (Решетар 1926: 112).

Најстарије сачуване покладне песме у Дубровнику су Ветрановићеве и оне представљају полазну тачку у проучавању дубровачких маскерата. Милорад Медини ове песме назива „праве покладнице” (Медини 1902: 146) и јасно издваја оне Ветрановићеве песме које припадају маскератној поезији (,Трговци Армени и Индијани”, „Двије робињице”, „Пастири” и „Ланци Алемани, трумбетари и пифари”). Након њега је П. Поповић ${ }^{6}$ истакао сличност Ветрановићевих маскерата са његовом песмом „Ремета”, да би М. Петковић „Ремета” дефинисао као „псеудомаскерату”, заједно са још три песме: „Орлача риђанка Котору говори проностик”, „Орлача риђанка Перашту говори” и „Орлача риђанка речено у Блату рибаром” (Петковић 1950: 112-113). Петковић је први у науци конкретно изложио зашто наведене Ветрановићеве песме

\footnotetext{
${ }^{6}$ Поповић истиче како песник у првом делу прича свој живот пун мука, на острвцету Св. Андрија, а све то „прича помало у шаљивом тону”, при чему је прилично живо и реално. У другом делу шаљиви тон уступа место дидактичном, „долазе аскетске идеје” и позивање људи на покајање и одбацивање раскоши и разврата (Поповић 1913: 146).
} 
- уз Сасинову „Робињицу”, Бобаљевићеву „Мајка Венера иште свога сина од ње изгубљена" и Ђурђевићевог Дервиша - сматра такозваним псеудомаскератама. Настојао је да потцрта разлику између маскерата с једне стране, и наведених песама сатиричке провенијенције у којима су, према његовом мишљењу, садржана обележја маскератне поезије; а будући да је увидео како се и поред сличности оне не могу изједначити са „правим маскератама”, дао им је одређење - „псеудомаскерате”.

У случају „Ремете” Петковић наводи разлоге због којих увиђа сличност са фирентинским маскератама: пустињак говори одакле долази и шта жели, односно, дошао је у град како би Дубровчане одвратио од порока. У трима песмама везаним за „Орлачу риђанку” која говори проностик, Петковић ову „сибилу” пореди са вилама сијенских цингарески јер и она прориче, наговештавајући своје натприродне способности. У науци су се овим проблемом бавили: Марин Франичевић (Франичевић 1983: 348), истичући како „Орлаче” јесу маскерате, а „Ремета” није; Мира Мухоберац (Мухоберац 2000: 753-757), која и „Ремету” и „Орлаче” сврстава у маскерате; док им Антун Павешковић (Павешковић 2012: 203) даје одређење „сатиричне маскерате”. У основи је извесно да оно што казивање Ремете одваја од карневалског манира јесте изразита ауторова побожност у обраћању суграђанима, у складу са начелима хришћанске ренесансе. У првој „Ремети” је одударање од маскератног начина певања истакнуто тоном својственим библијским јеремијадама, којим пустињак приповеда о тежини аскетског живота на пустом острву, супротним весељу и уживању у граду који је напустио; у циљу опстанка у пустопољини хвата „њорке” по стрмим стенама, стрепећи да не сломи врат, уместо да се попут својих суграђана разгали о покладама итд.

Друга песма „Ремета” такође нема суштинска својства маскерате, иако се у одређеним појединостима поклапа са маниром присутним у покладној поезији. Удаљеност од маскератног тона потврђује и пустињаков озбиљни говор испуњен спознајама о животу које је изнедрио контемплирајући у самоћи, а који упућује Дубровчанима уверен да ће на њих деловати. Обраћајући се женама као делу публике која прати казивање ремете, Ветрановић то чини на сасвим другачији начин него што је случај у маскератама. Уместо да своје слушатељке хвали, песник им преко Ремете упућује оштру критику и на начин друштвене сатире настоји постићи циљ супротан ласцивном удварању у покладним песмама. У песми нема ни оног неизоставног елемента предсказивања судбине ${ }^{8}$, својственог маскератама са једним казивачем. Ветрановићев пустињак у својој критици таштине - због које жене „гладе” лице, шепуре се као паунови носећи перје на шеширима, драгуље и велове - ствара контраст у односу на куртоазно удварање и дивљење физичкој лепоти у маскератама. Упозорава их на неизбежност смрти и на то да ће земљу „свеједно походити”.

\footnotetext{
${ }^{7}$ Pjesme Mavra Vetranića Cavčića, skupili V. Jagić i I. A. Kaznačić, JAZU, knj. III, Zagreb, 1871 (Ветрановић 1871).

${ }^{8}$ Прорицање судбине је у покладним песмама везано за жене које казују, то јест мушкарце преобучене у жене, јер се прорицања и врачања углавном везују за жене, које и јесу умешне у овим окултним вештинама (Кукљевић-Сакцински 1846: 86-104).
} 
Такво „прорицање” судбине од стране монаха, са подсећањем на неумитну смрт (memento mori), одудара од ведрих визија будућности и љубавне среће својствене маскератном казивању.

Оштра критика доминира и у говору Ветрановићеве пророчице Пераштанима, што је удаљава од дотицаја са маскератом, иако је мотив обраћања слушаоцима једина типолошка сличност. „Орлача риђанка Перашту говори” проричући његовим житељима мрачну будућност на много оштрији начин него што то чине прерушене прорицатељке у маскератама, када немилостивој госпођи неосетљивој на похвале и удварања предвиђају могућу будућност. Напротив, у Ветрановићевој песми се „сибила” млетачким поданицима обраћа уз изразите дисквалификације речима: „срамото крстјанска”, „лупешка похвало”, „Пераште проклети” и сл. Обиље погрда „махнитом Перасту” у супротности су са похвалним тоном у маскератама, док је једина афирмативна квалификација у песми везана за Дубровник и његовог небеског заштитника Св. Влаха који је Пераштане победио својим „штапиком од злата”. Иако се у песми упућеној Которанима - „Орлача риђанка Котору говори проностик” - пророчица огласила знатно блажим тоном, он никако не представља пандан говору у маскератама. Орлача се обраћа слушаоцима, у овоме случају Которанима, наступајући као саветодавка преко које Ветрановић исказује како антитурски став, тако и одиум према млетачкој охолости и претенциозности. Извесне аналогије са исказима маски у покладној поезији назиру се у благонаклоним саветима Орлаче Которанима: треба да се чувају Турака и моле се своме свецу заштитнику, Св. Трипуну. Иако се у оваквом тобожњем предсказивању слути трагична судбина Котора, кроз Орлачино обраћање слушаоцима се имплицитно очитује ауторов хришћански тон, пружајући извесну наду у опстанак Котора уколико се у потпуности окрену Богу и уздању у хришћанска начела; у противном, будућност ће бити тешка и невесела. Говор пророчице упућен је житељима Котора, а не искључиво женској публици; не ласка им, него дели трезвене савете у духу хришћанске ренесансе; могућа несрећна судбина наступиће због охолости и лојалности Млечанима, дакле, услед поступака који ни по чему не асоцирају на чулне жеље и љубавне мотиве маскератне поезије, него у првом реду настоје да у тону политичке сатире прикажу оновремени стварни живот и дубровачко окружење.

Уколико размотримо поменуте Ветрановићеве песме, увиђамо да прва и друга „Ремета” и песме у којима говори Орлача Риђанка, не могу бити дефинисане као маскерате, али ни као псеудомаскерате. Маскерате се као подврста покладне поезије свакако разликују од песама које садрже само обележја маскератне лирике. У том смислу, да би ове песме биле псеудомаскерате, морале би садржавати јасна обележја маскерате; напротив, овде су присутни само одређени покладни елементи, што их не чини маскератним жанром: по својој замисли и формалним обележјима оне нису намењене извођењу, те поетички не припадају лирици намењеној представљању о покладним светковинама. Обе „Ремете” су саздане у духу хришћанске ренесансе ${ }^{9}$, иако би

\footnotetext{
${ }^{9}$ Нема шале и ласцивности својствених маскератама, него се тежи осликати дубровачка стварност и друштвене реалије.
} 
ауторова замисао ремете, односно пустињака, који се обраћа фиктивној публици имало додирне тачке са покладним елементима. Међутим, ове песме нису компоноване по маскератном моделу, па самим тим не могу бити ни псеудомаскерате; у почетку се не успоставља контакт са присутном публиком којој би се ремета представио по узору на нпр. фирентинске маскерате (нема описа извесне професије, нити понуда одређених услуга). „Орлаче” су сатиричне песме испеване у облику пророчанстава (Бојовић 1994: 35), једно је било упућено Перасту, а друго Котору. Дакле, није реч о жанру псеудомаскерата, јер се ни сама прилика ове пророчице, сибиле, не појављује у покладном обличју, него као преносилац конструктивно-критичких порука самог аутора упућених Пераштанима и Которанима. Тон им је одмерен, насупрот маскератној лирици певаној о покладама, јер су настале као Ветрановићева критичка реакција на ласцивне садржаје оновремених дубровачких маскерата, какве су певане у ренесансном Дубровнику (многе од њих нису сачуване). Уношење оваквог критичког става у сатиричне опаске показује да казивање сибиле упућено дубровачким суседима неће изазвати штимунг својствен ведрој покладној атмосфери, мада вреди узети у обзир да су се маскерате такође изводиле и у време мимо поклада и нису стриктно везане за доба године када се одиграва карневал.

Песма „Робињица”"10 Антуна Сасина је према Петковићевој подели сврстана такође у псеудомаскерате ${ }^{11}$; поменути аутор сматра да она није испевана за покладне светковине, него је Сасин применио маскератни начин казивања у циљу опевања мотива робиње. Уколико размотримо ову песму, увиђамо начелне подударности са маскератном поезијом. Наиме, робиња хвали лепоту госпође чију самилост тражи у своме ропству; говори да долази из природног окружења у коме је срећно живела - у цветном перивоју са лепом дубравом обасјаном сунчевом светлошћу, брала је цвеће и проводила мирне дане; изриче жеље за добробит госпође уколико она буде милостива, а ове жеље се посредно подударају са „даровима” које обећава и песник у маскератним песмама приликом обраћања присутнима (да у миру проведе своју младост, да има наклоност Вишњег и срећу у љубави, да живи у изобиљу сребра и злата и свим благодетима). За узврат, као својеврсни вид „уздарја”, робиња само жели милост од господарице: „А ти госпо, ма липости, / не пореци нам милости!" (Сасин 1888: 168). С друге стране, појединост која не иде у прилог класификовању у маскерате, нити јој је својствена, јесте приповедање о сну као знамењу по коме ће ову девојку заробити гусари.

Венера из песме под насловом „Мајка Венера иште Купида, свога сина, од ње изгубљена"12 - Савка Бобаљевића, према мишљењу Миливоја Петковића, личи на „виленице” дубровачких покладних песама у своме ласкању

${ }^{10}$ Djela Petra Zoranića, Antuna Sasina, Savka Gučetića Bendeviševića, Stari pisci hrvatski, knj. XVI, JAZU, Zagreb, 1888, 166-168 .

${ }^{11}$ Петковићевој тврдњи о утицају раскоши италијанских карневала, И. Арсић супротставља став Петра Колендића који сматра да није у питању италијански изворник „Робињице” због њеног локалног колорита (Арсић 2002: 38-39).

${ }^{12}$ Pjesme Nikole Nalješkovića, Andrije Čubranovića, Miše Pelegrinovića i Saba Mišetića Bobaljevića i Jeđupka neznana pjesnika, Stari pisci hrvatski, knj. VIII, JAZU, Zagreb, 1876, 288-234. 
женама и навођењу окултне способности (Петковић 1950: 132) ${ }^{13}$. Појединост која се поклапа са маниром маскерате, јесте слика Венере која се одмах на почетку песме представља „госпојама” - као „божица од љубави” која је дошла да тражи свога сина Купида. Величајући лепоту присутних „вила”, Венера имплицитно исказује неверицу у успех потраге. Она прибегава једном гесту паралелном покладним песмама, нудећи присутнима награду уколико јој помогну; у овоме случају Венера наступа у складу са својом божанском јурисдикцијом - оној која јој доведе Купида и „у руке ме постави”, учиниће својим моћима да заувек има среће у љубави. Оваква моћ која надилази границе природног, посредно асоцира на „чини” којима располажу маскирани актери у карневалским песмама. Поред дарова које Венера госпођама обећава заклињући се како ће им „изпунити обећаје све љувене” (Бобаљевић 1876: 233 ) - као што чине Јеђупке у маскератама - не заборавља да опомене на последице које ће их снаћи уколико је разгневе. Венера је богиња и њена је моћ неизмерна - може присутнима загорчати живот, учинити га немирним и тужним као што с друге стране, у покладним песмама, невесела будућност лишена љубави чека охолу „госпу” која не хаје за удварања заљубљеног песника. У оба примера, ни песник прерушен у Јеђупку ни богиња Венера не наилазе на милостивост жена којима се обраћају. Извесно је да су сличности Бобаљевићеве песме и маскерате само начелне у наведеним појединостима, те се она по својим особеностима не би могла уврстити у жанр псеудомаскерате.

Комични спев из XVII столећа Стијепа Ђурђевића под насловом Дервищ $^{14}$ - М. Петковић такође сврстава у „семимаскерате” и приписује му маскератна обележја, заснивајући ово одређење на ставу да се аутор повео за фирентинским маскератама ${ }^{15}$. Најбитнију ознаку маскерате поменути аутор види већ на почетку песме, када се Дервиш представља и саопштава кога својим изгледом означава. Петковићево одређење је проблематично, с обзиром на присуство извесних, али никако доминантних елемента маскератног

${ }^{13}$ Петар Колендић сматра да је ова песма препев епилога Тасове Аминте (Колендић 1921: 44).

${ }^{14}$ Дервиш је у XVII столећу био сачуван у рукопису као и друга Ђурђевићева дела, изузев његовог препева Седам салама покорнијех краља Давида, који је једини био објављен. Петар Колендић је пре више од једног века пронашао један препис - „на неки начин зборник” песама, према његовим речима - који је припадао сабирачу дубровачких старина Дум Миху Караману. „У рукопису разма Јозефа праведнога и још некијех омањијех пјесама, има и чувени бисер васцијеле српско-дубровачке појезије пређашњијех вијекова, Дервишијада, Гундулићева савременика, Стијепа Ђорђића Гимана" (Колендић 1902: 751). Драгољуб Павловић истиче постојање пет рукописа Дервиша у Дубровнику. У питању су рукописи Фрањевачке библиотеке: бр. 40 (134), бр. 372, бр. 369, бр. 74 (346) и рукопис Градске библиотеке у Дубровнику; овај последњи рукопис је нарочито важан, јер се једино у њему налази тачно забележен датум песникове смрти (1632). По једној белешци, он је преписан са „већма старог рукописа” (Павловић 1971: 319). Дервиш С. Ђурђевића у целости је објављен у књизи Книжевност Дубровника-ренесанса и барок (Бојовић 2007: $232-239$ ).

${ }^{15}$ Стијепо Ђурђевић се угледао на шаљиве песме из италијанске ренесансне књижевности, нарочито песме Лоренца Медичија; као један од извора је Nencia di Barberino, чију је упоредну анализу са Дервищем извео М. Петковић (Петковић 1950: 339-347). Други Ђурђевићев значајан узор је италијански ренесансни песник Франческо Берни, који је поставио „темеље поетичко-стилског концепта који подразумева употребу особених језичких кодова и варирање стилских регистара, највише у пародијском кључу" (Петаковић 2014: 197). 
жанра. Аутор исказује нове, барокне погледе на феномен љубави; новину представља пародијски однос према истим оним појавама присутним код песника који великим делом преузимају петраркистички модел. Оно што би Дервиша могло довести у везу са маскератном поезијом, био би поступак карикирања петраркистичког начина певања (присутног у маскератама у којима су казивачи петраркистички љубавници), увођењем овешталих фраза које маске користе не би ли изазвале пажњу и наклоност жена у публици. Петраркизам је једним делом применио монолог костимираног лика незаобилазног у ренесансној маскерати, и поред тога што петраркистичка поетика нема народно-популарни, нити пригодни карактер.

Иако у XVII столећу долази до декаденције у развоју маскератног жанра, у науци је истакнуто како се у све већој мери огледа спрега покладне поезије и комичних спевова какав је Дервиш (Љубић 1869: 360; Стојановић 1900: 10). Милорад Медини (Медини 1902: 160) издваја овај комични спев као пример како се у XVII столећу ренесансна покладна лирика преобликује у хероикомичну песму. Милан Решетар се слаже са Мединијем и истиче да је Дервиш настао под утицајем маскератне поезије, али се сада обликовао тип „комичног несрећног љубавника" (Решетар 1926: 115). Миховил Комбол истиче да је Ђурђевић у устаљеном конвенционалном оквиру пружио „живахан мали спјев", са добро осликаним источњачким колоритом; то је монолог смешног старца „који узалуд уздише за „госпојом”, пијући „љути шербет својих суза” и пристајући већ и на то, да се због ње „хаин учини” Мухамеду. Такви ликови „смиешних удварача, који мјесто у сентименталном тону тадашњих идила говоре припростим језиком пуним шаљивих и неочекиваних обрта, били су већ одавно популарни у Италији, још од времена Лоренца де Медичи (Nencia di Barberino) и Луиђи Пулчија (Beca da Dicomano)" (Комбол 1945: 223). Значајно је истаћи да је Стијепо Ђурђевић кроз пародирање петраркистичке лирике у своме Дервишу исказао и општељудску жудњу за лепотом, која је недостижна. У тој естетској и филозофској спознаји лежи и Ђурђевићев дуг петраркистима и њиховој теми неуслишене љубави (Фрндић 1994: 152-162). Оригиналност Дервиша као првог шаљивог спева у дубровачкој књижевности, који представља пародију (Петаковић 2007: 69-73) петраркистичке лирике, истиче Злата Бојовић - пародија је „изведена на оригиналан начин и поред угледања на сличне италијанске спевове и шаљиве песме популарне још у XVI веку" (Бојовић 2014: 286). Дакле, Ђурђевић се није угледао на италијанске маскерате као основне изворе (према Петковићевом мишљењу) који би утицали на жанровско дефинисање Дервиша, него првенствено на италијанске рустикалне спевове и поезију из времена Лоренца Величанственог ${ }^{16}$. Вреди напоменути да овакви спевови са комичним удварањима и заклињањима, истицањем властитих врлина и нуђења разноразних дарова „немилостивој” госпођи, вуку порекло још из антике - од Теокрита (и њего-

${ }^{16}$ Највећи допринос је у том смислу пружила Фиренца за време владавине Лоренца Медичија, када се почињу одржавати карневалске светковине без премца, стварајући чаролију „која представља најблиставији фирентински допринос поетици светковина” (Шастел 2015: 224). 
вог Полифема), преко Овидијевих Метаморфоза, до Вергилијевог пастира Коридона у Еклогама.

Уз обиље турцизама кроз читав спев, Дервиш се већ на почетку представља као заљубљени - „ашик” дервиш, који „израњен” љубавним ранама пада „прид двор” немилостиве „госпоје”. Свестан да му је „вас труд заман”, Дервиш проклиње љубавну агонију и оног ко се узда у жене које за љубав не хају; стога је решио да више не копни за оном која му је душу огрешила и да је се најзад ослободи, не изостављајући прилику да наговести како ни она убудуће неће бити спокојна, јер ће је стићи праведан суд. У оваквом егзалтираном и гротескном наступу старог закрабуљеног „љубавника”, Стијепо Ђурђевић примењује барокни поступак искривљавања петраркистичких призора „анђеоске” лепоте, и прави рустикалне алузије потпуно супротне ренесансном виђењу идеализоване женске лепоте. Представљајући се у своме монологу као казивач који се удвара једној дами на балкону (а која се не издваја у скупини жена̂ као што је то случај у маскератама), при чему она за њега не хаје чак ни на помен дарова и „витешког служења”, па ни на претње самоубиством, Дервиш само у појединостима асоцира на покладне песме; не очекујући „уздарје” од охоле госпође, он на крају одустаје од удварања обећавајући сопствени „дар” у виду суда који ће је сустићи због немилостивости, што је и новина и одудара од наступа маскираног песника у дотадашњој маскератној поезији, па самим тим и у тзв. семимаскератама.

У наведеним делима се уочавају извесна обележја приметна и у маскератама, а по којима се са њима само начелно могу довести у везу. Иако су маскерате у Дубровнику одражавале изворни дух и атмосферу ренесансних покладних светковина, значајно је истаћи да су се оне изводиле и у време независно од покладног, па самим тим нису ни исказивале покладни дух. Ипак, дела овом приликом издвојена - означена условно као „псеудомаскерате” - и поред извесних обележја својствених казивачу у маскератама, жанровски се у њих суштински не уклапају. Ово је нарочито уочљиво на примерима Ветрановићевих „Ремета” и „Орлача”, лишених покладног штимунга у призорима оштре критике коју аутор на начин друштвене сатире и у складу са начелима хришћанске ренесансе упућује слушатељима; њихов одмерени и строги тон у супротности је са ведрим и „покладним” духом који неретко одликује маскератну поезију, али свакако није кључни разлог њиховог одвајања од псеудомаскерата извођених изван карневалских свечаности. Стално променљива и испреплетена природа жанрова онемогућава да се они увек стриктно дефинишу; остваривање једног жанра (у овом случају маскерате, али и псеудомаскерате) у индивидуалним текстовима могуће је повезати и ускладити са елементима другог, при чему једна књижевна врста доминира. У том смислу се и у дубровачким покладним песмама могу огледати елементи других жанрова, при чему је важно - како би се дело у основи дефинисало као маскерата, или псеудомаскерата - да примат имају суштинска обележја маскератама својствена, а не само посредно присутна, као што је случај са неколико наведених дела дубровачких аутора - од Мавра Ветрановића, преко Антуна Сасина и Савка Бобаљевића, до Стијепа Ђурђевића. 


\section{ЛИТЕРАТУРА}

Арсић 2002: И. Арсић, Антун Сасин - дубровачки песник XVI века, Бања Лука-Београд: Бесједа-Ars Libri.

Бобаљевић 1876: Pjesme Nikole Nalješkovića, Andrije Čubranovića, Miše Pelegrinovića i Saba Bobaljevića Mišetića i Jeđupka neznana pjesnika, SPH, knj. VIII, Zagreb: JAZU.

Бојовић 1994: 3. Бојовић, Мавро Ветрановић - Поезија и драме, Београд: Просвета.

Бојовић 2014: 3. Бојовић, Историја дубровачке къижевности, Београд: СКЗ.

Бојовић 2007: 3. Бојовић, Књижевност Дубровника - ренесанса и барок, прир. Злата Бојовић, Београд: Филолошки факултет, Крагујевац: Кораци, 232-239.

Ветрановић 1871: M. Vetranović, Pjesme Mavra Vetranovića Čavčića, knj. III, skupili V. Jagić i I. A. Kaznačić, Zagreb: JAZU.

Водник 1913: B. Vodnik, Povijest hrvatske književnosti, Zagreb: Matica hrvatska.

Грацини 1559: A. F. Grazzini, Tutti i trionfi, cari, mascherate ò canti Carnascialeschi andati per Firenze, del tempo del Magnifico Lorenco vecchio de 'Medici fino all anno 1559, Firenze.

3ope 1884: L. Zore, Gragja za poznavanje eroikomične Dubrovačke pjesme, LXXI, Zagreb: Rad JAZU, 145-175.

Јагић, Казначић 1871: Pjesme Mavra Vetranića Čavčića, skupili V. Jagić i I. A. Kaznačić, JAZU, knj. III, Zagreb.

Јиречек 1899: K. Jireček, Beiträge zur ragusanischen Litteraturgeschichte, Archiv für slavische Philologie, XXI, 425.

Колендић 1902: P. Kolendić, Nješto o Đorđićevoj „Dervišijadi”, Srd, 1, 16, 750-753.

Колендић 1921: П. Колендић, Бобаљевићев превод Тасова „Amor fuggitivo”, Наставник, XXIII, Београд, 44-46.

Комбол 1945: M. Kombol, Povijest hrvatske književnosti do preporoda, Zagreb: Matica hrvatska.

Кукуљевић-Сакцински 1846: I. Kukuljević-Sakcinski, Bajoslovlje i crkva: vile, Arkiv za povjestnicu jugoslavensku, I, Zagreb, 86-104.

Леви 1908: E. Levi, Lirica italiana antica. Novissima scelta di rime dei secoli decimoterzo decimoqvarto e decimoqvinto. Illvstrate con sessanta riprodvzioni di pittvre scvltvre miniatvre incisioni e melodie del tempo e con note dichiarative, Novamente stampato in Firenze.

Љубић 1869: Š. Ljubić, Ogledalo književne poviesti jugoslavjanske na podučavanje mladeži, Rijeka: Riečki Emidija Mohovića Tiskarski Kamen, Zavod, knj. II.

Медини 1898: M. Medini, Dubrovačke poklade u XVI i XVII vijeku i Čubranovićevi nasljednici, Program C. K. Velike državne gimnazije u Dubrovniku, 1897-98, Dubrovnik, 37-40.

Медини 1902: M. Medini, Povijest hrvatske književnosti u Dalmaciji i Dubrovni$k u$, I, Zagreb: Matica hrvatska.

Мухоберац 2000: M. Muhoberac, Vetranović, Mavro, Leksikon hrvatskih pisaca, Zagreb: Školska knjiga, 753-757. 
Павешковић 2012: A. Pavešković, Mavro Vetranović, Zagreb: Ex Libris.

Павловић 1954: Д. Павловић, Миливој Петковић „Дубровачке маскерате”, Прилози за књижевност, језик, историју и фолклор, Београд, 1-2, 339347.

Павловић 1971: Д. Павловић, Старија југословенска књижевност, Београд: Научна књига.

Петаковић 2007: S. Petaković, „Derviš” Stijepa Đurđevića - parodija petrarkističkog poetskog kanona, Svet reči, Beograd, god. XI, br. 23-24, 69-73.

Петаковић 2014: С. Петаковић, Реалистично-бурлескни свет дубровачког бернескног песништва, у: Ликови традииије, Београд: Завод за уџбенике, 195-206.

Петковић 1950: М. А. Петковић, Дубровачке маскерате, Посебна издања, књ. CLXVII, Одељење литературе и језика, Београд: САНУ, књ. 1.

Превитера 1939: C. Previtera, La poesia giocosa e l'umorismo dalle origini al Rinascimento, Milano: Vallardi, 204-221.

Поповић 1913: П. Поповић, Преглед српске књижевности, Београд.

Ракић 2013: Т. Ракић, Допринос Миливоја А. Петковића проучавању дубровачких маскерата, Прилози за књижевност, језик, историју и фолклор, Београд, 79, 287-295.

Решетар 1926: М. Решетар, Шаљива пјесма и сатира у нашој старијој литератури, Београд: СКГ, 111-122.

Сасин 1888: Djela Petra Zoranića, Antuna Sasina, Savka Gučetića Bendeviševića, SPH, knj. XVI, Zagreb: JAZU.

Стојановић 1900: I. Stojanović, Dubrovačka književnost, Dubrovnik.

Франичевић 1983: M. Franičević, Povijest hrvatske renesansne književnosti, Zagreb: Školska knjiga.

Фрндић 1994: N. Frndić, Jezični i sadržajni aspekti Đurđevićeva „Derviša”, Dani Hvarskog kazališta: Građa i rasprave o hrvatskoj književnosti i kazalištu, Vol. 20, No. 1, 152-162.

Шастел 2015: А. Шастел, Уметност и хуманизам у Фиренции у доба Лоренца Величанственог, Сремски Карловци-Нови Сад: Издавачка књижарница 3. Стојановића.

Gordana S. Pokrajac

CARNIVAL SPIRIT OF RAGUSEAN PSEUDOMASCERATES

(Summary)

Under the influence of Italian carnival, Ragusean carnival poetry also developed. However, Ragusean Renaissance poets created carnival songs even in the situations without carnival atmosphere. This is specific phenomenon so called "pseudomascerates", such as some works of: Mavro Vetranović, Antun Sasin, Savko Bobaljević, Stijepo Đurđević and the others. In this work we will try to point to main examples, which are not actually pseudomascerates, even though they have some characteristics of this literary genre. 